\title{
Fakery and Wealth in African Charismatic Christianity: Moving beyond the Prosperity Gospel as Script
}

\author{
Karen Lauterbach
}

The prosperity gospel - the promise of abundant wealth as a sign of God's blessing - is one of the most prominent features of charismatic Christianity in Africa, and also one of the most contested. In many of the popular charismatic mega-churches in Ghana, Kenya, Nigeria, and Uganda, pastors preach the health and wealth gospel; they promise material wealth to congregants as a sign of God's blessing and at the same time strongly encourage church members to give generously in church. Many prosperity pastors are themselves illustrations of what they preach, living in big houses and driving luxury cars; some even have private jets. People flock to the prosperity churches in search of health and wealth, ${ }^{1}$ yet the prosperity gospel is also contested terrain. There are numerous cases of charismatic pastors being accused of fraud and criminal activities. Moreover, charismatic pastors are criticized by leaders of other Christian denominations as being fake or for representing an unethical and misunderstood form of Christianity. ${ }^{2}$ The above depiction and criticism of the prosperity gospel - appearing both in public and academic debates - touch upon a perceived irreconcilability between Christian faith and the idea of giving to God with the expectation of receiving a return (a blessing). Such a reading furthermore prioritizes an understanding of the prosperity gospel as a coherent

1 Paul Gifford, Ghana's New Christianity: Pentecostalism in a Globalising African Economy (London, Hurst \& Company 2004); Ebenezer Obadare, “'Raising righteous billionaires': The prosperity gospel reconsidered," HTS Teologiese Studies/Theological Studies 72, no. 4 (2016): 1-8.

2 Ilana van Wyk, The Universal Church of the Kingdom of God in South Africa: A Church of Strangers (Cambridge University Press 2014); Karen Lauterbach, Christianity, Wealth, and Spiritual Power (New York: Palgrave Macmillan 2017), 77-82. See also "The prosperity gospel makes a mockery of Christianity," The Guardian, 29 May 2013, https://www.theguardian. com/commentisfree/andrewbrown/2013/may/29/prosperity-gospel-mockery-christianity (accessed 9 December 2017) as an example of how African prosperity gospel is discussed in the media. 
system of thought - or as script - and thereby excludes other moral principles of giving and receiving in a given religious context that may exist.

In many ways scholarship on the prosperity gospel in Africa mirrors similar positions. One strand of the theological literature sees the prosperity gospel as bad and misunderstood theology mainly because it links faith with material and this-worldly success, thereby promoting an understanding of people's relationship with God to be about receiving from God rather than serving God. The prosperity gospel is further criticized for being consumer-oriented and materialistic, and hence more in conjunction with secular, market-driven ideology than Christian theology. ${ }^{3}$ Other theologian scholars, such as Pentecostal theologian Amos Yong, view the prosperity gospel through a more positive lens and highlight, for instance, the prosperity gospel's contribution to different aspects of the economic field. ${ }^{4}$

Some of the social science literature on charismatic Christianity in Africa takes a critical stance towards the prosperity gospel, in particular with regard to what this strand of Christianity can produce in terms of social equality and democratization. One argument promoted by Paul Gifford is that the teachings of the prosperity gospel hinder development in Africa, as they take away individual responsibility and ignore the role of social structures when explaining poverty and unequal access to material wealth. ${ }^{5}$ In addition, there is an expanding literature that analyses the prosperity gospel from an anthropological perspective. Common to many of these studies is that they seek to understand the attractiveness of the prosperity gospel from the point of view of church members, pastors, and other actors. In this, they employ a relativist approach that tries to avoid moral condemnation of the preachers and practitioners of the prosperity gospel and read the situation in a culturally and contextually informed way. ${ }^{6}$ Nevertheless, these studies at times have a more im-

3 Milmon Harrison, Righteous Riches: The Word of Faith Movement in Contemporary African American Religion (Oxford: Oxford University Press 2005); Mika Vähäkangas, "The Prosperity Gospel in the African Diaspora: Unethical Theology or Gospel in Context?," Exchange 44 (2015): 353-380.

4 Amos Yong, "A typology of prosperity theology: A religious economy of the global renewal or a renewal economics?," in Pentecostalism and prosperity: The socioeconomics of the global charismatic movement, eds. Katherine Attansi and Amos Yong (New York: Palgrave Macmillan, 2012), 15-33. For further debate see also Andreas Heuser, "Charting African Prosperity Gospel economies," HTS Teologiese Studies/Theological Studies 72, no. 4 (2016): 1-9.

5 Paul Gifford, Christianity, Development, and Modernity in Africa (London: Hurst \& Company, 2015); Obadare, "Raising."

6 Girish Daswani, "A prophet but not for profit: ethical value and character in Ghanaian Pentecostalism," Journal of the Royal Anthropological Institute 22, no. 1 (2016): 108-126; Naomi Haynes, "Pentecostalism and the morality of money: prosperity, inequality, and religious 
plicit moral bearing in the sense that they seek to explain, for instance, why people spend amply in church if they lack food and medicine, hence implying that this is irrational.

Despite the different analytical approaches taken by various scholarly disciplines, most perceive and analyze the prosperity gospel as script. By this, I mean that they understand the prosperity gospel as a coherent system of religious thought, or as prosperity theology or ideology. It is common, for instance, to locate the roots and hence the basic principles of the prosperity gospel in American versions of Pentecostalism that emerged in the 1940s and 1950s. Many refer to American preachers and evangelists such as Kenneth Hagin, Kenneth Copeland, Oral Roberts, and T.L. Osborn when tracing its origins. ${ }^{7}$ The ideological content of the prosperity gospel is then described in relation to this history and viewed grosso modo as a coherent system of thought that has been transplanted from one place to another, one which is static and timeless. This has analytical implications. By foregrounding an idea of the prosperity gospel as a system of thought, the analyses "see" this system rather than other parallel ideas of giving and receiving that involve the spiritual realm and that might or might not be located in a Christian context. The point is that despite analytical efforts to contextualize the prosperity gospel, there is a strong tendency in the literature to perceive the prosperity gospel as a collection of preset principles, rather than to attempt to dismantle the underlying principles of giving and receiving that might be located inside as well as outside of the charismatic Christian setting. Such an analytical dismantling is particularly relevant with respect to one of the main tropes in the literature, namely, the forms of wealth that are morally acceptable and legitimate in religious settings in Africa. Therefore, I propose that focusing more broadly on how people understand and practice giving and receiving in church is more illuminating than a focus on how and why the prosperity gospel is attractive in African contexts. Instead of taking the prosperity gospel as the analytical focus, I suggest that studying different modalities of exchange provides a broader understanding of

sociality on the Zambian Copperbelt," Journal of the Royal Anthropological Institute 18, no. 1 (2012): 123-139; Martin Lindhardt, "More than just money: The faith gospel and occult economies in contemporary Tanzania," Nova Religio: The Journal of Alternative and Emergent Religions 13, no. 1 (2009): 41-67; Ilana Van Wyk, The Universal. See also Joel Robbins's chapter for a more comprehensive discussion of this approach.

7 Paul Gifford, "The complex provenance of some elements of African Pentecostal theology," in Between Babel and Pentecost, eds. André Corten and Ruth Marshall-Fratani (Bloomington and Indianapolis: Indiana University Press, 2001), 62-79; Heuser, "Charting"; J. Kwabena Asamoah-Gyadu, African Charismatics. Current Developments within Independent Indigenous Pentecostalism in Ghana (Leiden: Brill, 2005). 
what is considered legitimate and what is considered dubious or fake in the charismatic Christian context and beyond.

This chapter offers a critical reading of the literature on the prosperity gospel and argues that, by approaching the prosperity gospel as a bounded and unified system of religious thought, there is a risk of ignoring how some of its basic mechanisms reflect similar mechanisms within other religious traditions or in society more widely. One way of avoiding this is to maintain a focus on modalities of exchange, which, as an analytical perspective, offers a broader reading of the moralities around wealth in religious fields. ${ }^{8}$

In a recent publication, Simon Coleman discusses prosperity Christianity with a focus on the resonances between this religious ideology and ideas associated with the "free market." The discussion relates in particular to the role of risk and uncertainty in the relationship between the prosperity ideology and the market and seeks to question established oppositions such as gift versus commodity, mutuality versus self-interest, and altruism versus greed. Coleman uses the prosperity gospel as a lens to discuss the ascetic assumptions that lie behind perceptions of the prosperity gospel as immoral. ${ }^{10}$

I seek to draw parallel lines with discussions of what is perceived as illegitimate and legitimate wealth in charismatic Christian settings, thereby discussing broader moralities of wealth and relationships of exchange. I find the prosperity gospel a useful entry point into these discussions because its rhetoric, practices, and underlying values spark debate. In other words, I propose studying the prosperity gospel as a way to analyze broader moral ideas around fakery and wealth, rather than seeing the prosperity gospel as a script to which people adhere. This provides insight into the relationships between religion, wealth, and morality that are about more than the prosperity gospel in a dogmatic sense. Thus, I approach prosperity as relationships of exchange that take place in recent being" and open religious fields (such as charismatic Christianity), and as relationships in which the boundaries of what is considered legitimate and illegitimate prosperity (and ways of acquiring it)

8 Frederick Klaits, "Asking in Time," in The Request and the Gift in Religious and Humanitarian Endeavors, ed. Frederick Klaits (Cham: Palgrave Macmillan, 2017), 1-24.

9 Simon Coleman, "Morality, Markets, and the Gospel of Prosperity," in Religion and the Morality of the Market, eds. Daromir Rudnyckuj and Filippo Osella (Cambridge: Cambridge University Press, 2017), 50-71.

Ibid., 55 . 
are contested and reshaped. I follow Coleman in seeing "prosperity discourse as a site of practice" where common assumptions and ideas about religion, wealth, and relationships of exchange can be examined. ${ }^{11}$

When particular ideas or practices of the prosperity gospel are contested and seen as fakery or abuse, it is the accusations and contestations in themselves that are interesting to study because they shed light on how ideas and practices of wealth are changing in society. It is particularly stimulating to study the relationship between prosperity and fakery in the religious field because "issues of right and wrong become muddled when alleged supernatural forces and subjective hopes and expectations enter the equation," as Amanda van Eck Duymaer van Twist has pointed out. ${ }^{12}$ Studying the ambiguous relationship between wealth and religion is an entry point into moral discussions of legitimate and illegitimate wealth more generally. Moreover, taking this perspective when studying the prosperity gospel can bring new insights to perceptions of the affinities between charismatic Christianity and broader social conjunctures. Ultimately, these insights add to our understanding of why the prosperity gospel in African charismatic Christianity is so prominent and yet contested at the same time, in a way that does not see concurrent prominence and contestation as a contradiction in itself.

A dialogue between anthropology and theology can be fruitful in this analytical work. Both disciplines, or, rather, sub-disciplines within their broader disciplines, invite us to take religious values, experiences, and ideas seriously. Both disciplines offer conceptual frameworks that reach outside the boundaries of the prosperity gospel as script. Anthropology provides an analytical language with which to understand relationships of exchange, gift-giving, and reciprocity. This scholarly field draws in particular on Marcel Mauss' classical work on gift-giving, and giving as a moral act and source of morality. Building on Mauss' framework, Frederick Klaits posits the act of asking as similar to that of giving and argues that, "the moral qualities of giving and asking, expressed through words, objects, and texts, contribute to the ways in which persons are valued and devalued."13 As a way of conceptualizing the obligations that asking and giving confer, Klaits identifies (drawing on David Graeber in this) a number of modalities of exchange that each signify different sources of obligation, influence on personal value, and the nature of trust. The economic modalities are "baseline communism," "free gift," "exchange," and "hierarchy," and differ,

\footnotetext{
$11 \quad$ Ibid., 62.

12 Amanda van Eck Duymaer van Twist, "Introduction," in Minority Religions and Fraud: In Good Faith, ed. Amanda van Eck Duymaer van Twist (London: Ashgate Publishing, 2014), 2.

13 Klaits, "Asking," 2.
} 
briefly put, with regard to the moralities around asking and giving. Baseline communism, for instance, builds on the moral principle of sharing, in which "one's rights to resources depend on one's willingness to share."14 Within the free gift modality of exchange, gifts are given without a perceived obligation to return and asking is generally absent or disguised. In the hierarchy modality, exchange takes place between persons in different positions in a hierarchy, such as between church leaders and members, and the exchange often reinforces these positions. Drawing on this conceptual language in the study of how wealth is legitimized and delegitimized in charismatic Christianity allows us to interpret the language of the prosperity gospel in a broader and more dissected manner. Giving in church can be linked to expectations of being successful in this world in different ways, and not all are necessarily related to the problem of having a commodified approach to Christianity, as referred to above.

Likewise, there are branches of theology that go beyond a systematic approach, and focus on how religious ideas are formulated and practiced at the ordinary level. By including both official/intellectual discourses and religious thinking by church members and other lay people, this approach offers a frame with which we can analyze religious thinking at an academic and an ordinary level. A focus on ordinary theology serves to supplement the existing focus on official doctrine in studies of the prosperity gospel in African religious settings. Ordinary theology sheds light on theological ideas and thoughts expressed by those who participate in religious communities and activities, but who are not normally considered religious experts. ${ }^{15}$ According to Jeff Astley, ordinary theology is, moreover, ordinary in the sense that it reflects the everyday life experiences of people and, drawing on Edward Farley, he argues that it represents "wisdom proper to the life of the believer." ${ }^{6}$ Ordinary theology, one could say, is similar to anthropological studies of Christianity in its focus on empiricaldescriptive aspects of theology and religious practice. This is helpful for the purpose of this chapter as it permits to have a focus on the moralities of giving and receiving in church as they are formulated and enacted both by church leaders and members. These moralities are not implemented from above and do not travel via American evangelists; rather, they are formulated

\footnotetext{
14 Ibid., 7 .

15 Jeff Astley, "The Analysis, Investigation and Application of Ordinary Theology," in Exploring Ordinary Theology: Everyday Christian Believing and the Church, eds. Jeff Astley and Leslie J. Francis (Farnham: Ashgate Publishing, 2013), 1-9.

16 Edward Farley, 1983: 35, cited in Astley, "The Analysis," 2.
} 
in the encounter between religious discourse and other discourses that relate to moralities of giving and receiving.

Combining the two approaches is fruitful in the sense that a focus on ordinary theology places a stronger emphasis on religious ideas and thinking manifested at an everyday (ordinary) level that is often not part of anthropological and sociological studies of the prosperity gospel. In the same vein, Joel Robbins calls for "critically studying the theologies we find in the field."17 This enables the inclusion of theological engagements and ideas that are not part of academic theology, but that represent debates and reflections on religious ideas that are connected to everyday life and are part of the ordinary. This is, moreover, a way of taking religion seriously as part of everyday life, not only as practice or belief, but as intellectual engagement. A focus on ordinary theology in combination with an anthropological insistence on religion in context allows for an analysis of the prosperity gospel as an ideological and intellectual frontier where ideas and practices of wealth are contested and debated.

\section{3}

The Script

Claiming this-worldly success and seeing material riches as a sign of God's blessing are central features of the prosperity gospel. This is enacted through ritual practices such as the giving of offerings and tithes, and pastors preaching and praying about the blessings. The fundamental idea of the prosperity gospel is illustrated by the "sowing and reaping" metaphor, which implies that church members must sow tithes and offerings in church in order to reap a harvest of wealth and success. Believers of charismatic Christianity are seen as having a biblical right to enjoy riches and prosperity. The principle of giving and receiving (sowing and reaping) is the rationale behind receiving the blessings of God: the more one gives in church the more one receives from God. ${ }^{18}$ Pastors teach church members how to give freely and spontaneously. This principle builds on the unique relation between man and God - you give as an individual person and God gives back to you as an individual. As Andreas Heuser has pointed out, the prosperity gospel, and the theology of "seed faith," links faith and action: "it is practical theology, so to speak, with a strong call to enactment."19

17 Joel Robbins, "Afterword: Let's keep it awkward: Anthropology, theology, and otherness," The Australian Journal of Anthropology 24, no. 3 (2013): 330.

18 On the theological background of this principle, see Asamoah-Gyadu, African Charismatics.

19 Heuser, “Charting," 3. 
What members give in church is perceived as something they give to God, which means that giving to the church or the pastor is the same as giving to God.

Although the prosperity gospel builds on the idea of faith as the starting point for receiving blessings, some scholars have argued that the language used to explain the principles of giving and receiving is often an economic one, underpinned by assumptions of calculated return. Giving is talked about as an investment and receiving as the fruits one harvests from that investment. ${ }^{20}$ This is linked to how the appeal and attractiveness of charismatic Christianity is explained, namely, that people come to church to seek success in life - such as in business, marriage, education, in getting a visa, and travel - and to achieve social mobility. ${ }^{21}$ The strong focus on success and prosperity is, in other words, understood to make charismatic churches attractive and as being in consonance with people's aspirations for a modern life. There is, therefore, a close link between the religious message and the everydayness of peoples' lives.

This economic reading of the prosperity gospel is also reflected in scholarly debates that connect the prominence of the prosperity gospel to the emergence of millennial capitalism and neo-liberalism. The much-cited work of the Comaroffs reads the prosperity gospel and the rise of occult economies as a new protestant ethic: a response to a new spirit of capitalism wherein spiritual rewards are bestowed instantly and take the form of material wealth. ${ }^{22}$ This frame of explanation highlights the irrational and the occult as responses to life conditions marked by lack, loss, and disempowerment, as well as to forces of global capitalism. It moreover sees religion and religious services as commodities and therefore promotes a market analogy (for instance seeing religion as a reflection of a market model, and paying tithes or offerings as investments). In relation to the purpose of this chapter, the different ways of reading the relationship between religion and wealth are relevant, because they reveal some of the underlying ontological premises on which they build. Filippo

20 On religion and investment, see Karen Lauterbach, "Religious Entrepreneurs in Ghana," in Cultural Entrepreneurship in Africa, eds. Ute Röschenthaler and Dorothea Schultz (Routledge, 2016), 19-36.

21 Asonzeh F-K. Ukah, "Those who trade with God never lose: The economics of Pentecostal activism in Nigeria," in Christianity and social change in Africa: Essays in honor of J.D.Y. Peel, ed. Toyin Falola (Durham, Carolina Academic Press, 2005), 253-274.

22 Jean Comaroff and John Comaroff, "Second comings: neo-Protestant ethics and millennial capitalism in Africa, and elsewhere," in 2000 Years and Beyond: Faith, Identity and the 'Common Era', ed. Paul Gifford (London: Routledge, 2003), 106-126. For a discussion of analyzing the prosperity gospel as protestant ethic see also Birgit Meyer, "Pentecostalism and Neo-Liberal Capitalism: Faith, Prosperity and Vision in African PentecostalCharismatic Churches," Journal for the Study of Religion 20, no. 2 (2007): 5-28. 
Osella and Daromir Rudnyckyj, for instance, make the point that the Comaroffs' analysis of charismatic Christianity, as a response to millennial capitalism, fosters an ethic of new consumerism and individualism, and that this rests on a particular idea of the relationship between religion and the market as separate categories. Therefore, "in their account new forms of religiosity are eventually reduced to instances of false consciousness." ${ }^{23}$ The analysis of the Comaroffs (and others) represents a certain implicit moral stance on the relationship between religion and wealth, and, more broadly, on the relationship between the modern and the religious. In this way, discussions of fakery and morality in relation to wealth and religion take place at many different levels, and are not only about the prosperity gospel as a religious set of ideas or theology, but also about how the modern and relationships of exchange are perceived contextually and historically.

Beyond the Prosperity Gospel as Script

As mentioned in the beginning of this chapter, the prosperity gospel is both a contested and an attractive aspect of charismatic Christianity in Africa. Some of the controversies touch upon whether the insistence on giving plentifully in church is a way of exploiting and abusing the poor, in particular if people are given empty promises of material blessings. ${ }^{24}$ Such controversies reflect two overall understandings of the relationship between wealth and religion. First, the prosperity gospel provokes reaction and debate as it challenges the understanding that the market or capitalism is secular and therefore inherently different from religion and religious values. Second, it penetrates the core of what is considered Christian ethics (mainly in Western protestant Christianity) in which giving is considered a disinterested act and abundant wealth is seen as contradicting Christian values. ${ }^{25}$ Therefore, from these perspectives, encouraging people who have little to give money in church is perceived as immoral.

Some years back, I had a conversation with a Ghanaian female pastor who argued in a different way. She was of the view that pastors should not ask for too much money in church, but at the same time argued that pastors should

23 Filippo Osella and Daromir Rudnyckyj, "Introduction: Assembling Market and Religious Moralities," in Religion and the Morality of the Market, eds. Daromir Rudnyckuj and Filippo Osella (Cambridge: Cambridge University Press, 2017), 6.

24 See Lauterbach, Christianity, Chapter 3 for a discussion of this in the Ghanaian context.

25 See also Simon Coleman, "Between Faith and Fraudulence? Sincerity and Sacrifice in Prosperity Christianity," in Minority Religions and Fraud. In Good Faith, ed. Amanda van Eck Duymaer van Twist (London: Ashgate Publishing, 2014), 73-89. 
not prevent church members from receiving the blessings of God. She saw "sowing seeds in church" as a necessary form of giving, and if this was prevented it would hinder churchgoers from receiving God's blessings, but also from being mature Christians. ${ }^{26} \mathrm{Her}$ argumentation was that sowing was not only about receiving material blessings, but also had the aim of being able to grow as a religious person. In this account, there is necessarily a distinction between giving from a self-interested and a disinterested perspective. Moreover, the pastor made a distinction between legitimate and illegitimate ways of collecting funds in church, to which I return below. This example shows that the moralities connected with giving and receiving in a religious setting do not necessarily follow the same rationalities, and that in some instances giving in church can be about more than securing a material return.

Another line of criticism expressed in discussions of the prosperity gospel centers around the problem of deception. The argument is that if people have been promised God's blessings (in the shape of a new car or a visa, for example) in church, and they do not receive these objects, a reaction of distrust and feelings of being deceived must follow, and eventually they will leave the church. This is, however, a highly utilitarian way of perceiving how people relate to wealth in religious settings. The question is whether we can take for granted that the items promised and wished for, are expected to materialize. Promises of material wealth can also symbolize hope and an idea of possibility. As Lindhardt has pointed out, "the Faith gospel provides ways of dealing with the moral and perceived dangerous aspects of wealth and accumulation,"27 and therefore does not necessarily symbolize a relation of exchange in a literal sense. The prosperity gospel with its strong focus on wealth can also be understood as a field in which the boundaries of what is legitimate and illegitimate wealth are pushed and redefined, as mentioned above. We cannot assume that what is perceived by some as failed promises are perceived in a similar manner by others, or that failed prophecy only leads to dissolution. Moreover, discrepancies between what a pastor preaches and promises and what a church member experiences and receives is not automatically read as failure or fakery. There are many historical examples of the contrary, such as very specific promises of the second coming of Christ or the destruction of the world. ${ }^{28}$

In a similar vein, Johannes Fabian draws attention to "confusions" in some of the terms we use when analyzing charismatic Christianity and warns against

26 Interview with pastor, 3 December 2014, Kumasi, Ghana..

27 Lindhardt, "More than just," 42.

28 See Leon Festinger, Henry W. Riechen and Stanley Schachter, When Prophecy Fails (Minneapolis: University of Minnesota Press, 1956). 
blending analytical concepts with self-designated terms: "I don't think we should narrow down the meaning of charismatic to a self-designation of one manifestation of neo-pentecostalism." ${ }^{29} \mathrm{He}$ argues that charisma as an analytical concept is broader than what lies within the term charismatic as it is used when describing charismatic Christianity. I think the same argument is valid when we talk about prosperity; prosperity can be used as a broader analytical concept and should not be confined to what lies in the prosperity gospel script. As an analytical category, prosperity draws from a broader pool of theoretical ideas on relationships and modalities of exchange, for instance. The importance of being aware of such distinctions in the use of terms such as charismatic, religion, and prosperity is, according to Fabian, linked to the crucial insight that concrete religious acts or messages also relate to abstract ideas. This is of relevance when discussing how to analyze and make sense of the prosperity gospel. Fabian writes:

On the level of intellectual content, a charismatic leader attracts followers, not because of specific skills he or she has, or because of goods he promises, but because every specific "miracle" he performs serves a universal message ... Healing is directed against universal suffering, divination is about uncertainty as a general state, not just about a given case. ${ }^{30}$

This broader way of approaching the use of such concepts echoes Lindhardt's point, mentioned above, that the prosperity gospel is a way of handling the uncertainties associated with accumulating wealth. As such, the prosperity gospel is not only about the concrete acts of "sowing and reaping" or of offering in church and receiving wealth as a sign of God's blessing. Giving in church is also a way to deal with the relationship between human and God, and with moral questions concerned with giving and receiving in a religious field. Fabian sees a tension in charismatic Christianity between delivering messages at the universal level and at the same time representing a commodified form of religion, and asks whether this commodification will influence the ability to tackle moral questions at a more abstract level. This is a relevant but difficult question to debate in general terms but, as I discuss below, charismatic Christianity and the prosperity gospel do not necessarily represent a commodified form of religion that does not allow room for dealing with moral questions. The debates around wealth and fakery that are prominent in charismatic

29 Johannes Fabian, Talk about Prayer: An Ethnographic Commentary (New York: Palgrave Macmillan, 2015), 18.

$30 \quad$ Ibid., 21. 
Christianity are good examples of this, and it might be that the idea of a commodified form of religion lies more in the script than in the enactments and negotiations of charismatic Christianity.

As discussed above, the literature on charismatic Christianity has, to a wide extent, approached the prosperity gospel as a coherent system of thought or as an ideal type. Andreas Heuser, among others, argues that the prosperity gospel as a theological message in a distilled form is always adapted and translated in different contexts, but this acknowledgement of cultural adaptation does not transcend beyond the message (or script) itself. ${ }^{31}$ We often do not learn much about how the universal or moral messages that are also part of the prosperity gospel are embedded in different cultural and historical settings and resonate with the moral concerns in these contexts.

Another way in which the prosperity gospel is approached as a single message is in attempts to quantify its reach. Heuser, for instance, refers to a Pew study that shows that fifty percent of African Christians "believe in the Prosperity Gospel - that God will grant wealth and good health to people who have enough faith." ${ }^{32}$ It is of course important to have a solid idea of the prominence and spread of the prosperity gospel, but it is worth reflecting more on what it means when someone says he or she believes in it and to what extent it is perceived as a single message. More particularly, it is important to dig into how believers understand the relations of exchange between themselves and God, as such relationships might reflect ideas of giving and receiving in a religious context that do not necessarily stem from charismatic Christianity itself. Rather than only talking about a "Pentecostalisation of African religious landscapes" 33 it is also necessary to pay attention to how other religious traditions and moral ideas are reflected in the prosperity gospel.

In addition, when analyzing the relationship between the prosperity gospel and processes of social, political, and economic change it is problematic not to unpack the prosperity gospel as a singular theological message. ${ }^{34}$ This line of analysis presupposes that there is such a thing as a shared understanding and acceptance of the prosperity gospel and that this theology shapes people's actions and moral values. Yet there is little analytical space to capture how the prosperity gospel is interpreted in the lives and practices of people. When Heuser, for instance, argues that "unparalleled in African postcolonial history a single theological imagery evolved as a potential motivational porter of social

$31 \quad$ Heuser, "Charting."

32 Pew Forum 2010, cited in Heuser, "Charting," 2.

33 Ibid., 2.

34 See for instance Yong, "A typology." 
transformation," ${ }^{35}$ we do not delve much into how ideas of giving and receiving in a religious context shape social change. In sum, by seeing the prosperity gospel as a single theological imagery - or as script - we fail to see how ideas of giving and receiving are present in other parts of society and how these ideas resonate with those promoted in the prosperity gospel. Or, in the words of Max Weber, "the manner in which ideas become effective forces in history." 36

By removing the emphasis on the prosperity gospel as a single message, it is possible to get a better sense of the broader mechanisms that the theological metaphor of sowing and reaping represents. To what extent is giving and receiving in this religious field something particular to it, and to what extent a reflection of broader mechanisms found elsewhere in a given society? When Heuser writes that, "In its core, Prosperity Gospel theologizes on the interplay between faith and action; it is practical theology, so to speak, with a strong call to enactment, ${ }^{\prime 37}$ one could argue that faith in action, or faith as action, is a common trait of many religious fields in different African contexts. Various authors have pointed out that religion in African contexts is often much more about practice and everyday life than about faith as an inner state. J.D.Y. Peel, for instance, has discussed how everyday routines and practices are part of the Yoruba understanding of religion. ${ }^{38}$ Therefore, it is also relevant to interpret the prosperity gospel in relation to, and as reflecting, practices of giving and receiving in wider religious fields. Approaching the prosperity gospel as script somehow reflects a tendency in the literature on religion in Africa to view religious worldviews (or cosmologies) as coherent systems of ideas, juxtaposing, for instance, Christian worldviews and traditional religious worldviews. These categorizations allow for comparison and for tracing change and continuity, but they also reiterate these worldviews as stable and timeless and reduce our ability to see values and practices that cross the boundaries of these categories. In other words, the prosperity gospel can be analyzed as reflecting current debates on legitimate and illegitimate ways of accumulating wealth, debates that are not new to these societies, but to which the prosperity gospel adds a new way of articulating such tensions.

35 Heuser, "Charting," 2.

36 Max Weber, The Protestant Ethic and the Spirit of Capitalism (London: Routledge, [1930] 2001), 48.

37 Heuser, "Charting," 3.

38 J.D.Y. Peel, Religious Encounter and the Making of the Yoruba (Bloomington, Indiana University Press, 2000). 
The prosperity gospel as a field of contestations over the accumulation of wealth is often linked to accusations of fakery and fraud. Fakery touches upon the legitimacy of the accumulated wealth as well as the intentions of a religious leader or provider of religious services. In many African contexts, accusations of fakery in the religious field are about how wealth is accumulated and redistributed, and fakery and exploitation are issues that are often discussed in relation to the prosperity gospel. Prosperity churches are accused of exploiting the poor, their pastors are accused of being fake pastors, and they are seen as hindering social development. One among many examples is an interview with a renowned and high-ranking Methodist minister in Ghana in which he publicly accused charismatic pastors of "exploiting the poor" in a national newspaper. The minister highlighted in particular that these churches extract money from their poor members and described them as a, now late, "machinery for money making" that do not provide any form of social services in return. Moreover, he complained that pastors of the charismatic churches are self-ordained (implying they have not been through formal theological training at a seminary), and hence that they are fake pastors. ${ }^{39}$ In this example, it appears that fakeness is related to not contributing to social well-being more broadly and not pursuing formal and recognized career paths.

Martin Lindhardt points out that with the pluralization and commercialization of Christianity in Africa has come greater suspicion of fraud ${ }^{40} \mathrm{He}$ also argues that this does not imply that the accumulation of wealth in a religious setting is morally contested in itself. It is rather that when "Charismatic ministry in too obvious ways becomes a business venture and when adherents or consumers fail to see the material fruits of spiritual assistance," accusations of fraud and fakery appear. ${ }^{41}$ In pointing this out, Lindhardt also argues that it is not the connection between religion and wealth that is problematic in itself but, rather, more subtle distinctions between legitimate and illegitimate ways of accumulating wealth in charismatic churches. He highlights religious services as a way to earn money per se and deception as two key moral concerns.

39 The Daily Dispatch, 7 September 2005. See also Lauterbach, Christianity, 65.

40 Martin Lindhardt, "Miracle Makers and Money Takers: Healers, Prosperity Preachers and Fraud in Contemporary Tanzania," in Minority Religions and Fraud. In Good Faith, ed. Amanda van Eck Duymaer van Twist (London: Ashgate Publishing, 2014), 153. 
The above observations suggest analyzing the prosperity gospel in terms of modalities of exchange in order to capture the different norms and criteria that are being drawn upon in ethical considerations of what is legitimate or illegitimate: for instance, in assessing providers of religious services as either fake or genuine. In my work on charismatic Christianity in Ghana, I have discussed wealth as a topic that is central to discussions of fakeness. ${ }^{42}$ An important debate and tension is about whether one accumulates for the community or whether one accumulates for oneself. Historically, chiefs and big men were expected to accumulate wealth and to display this wealth publicly, but they were at the same time responsible for the well-being of the community. This tension is reflected in the comments and accusations of the Methodist minister mentioned above. He uses the argument that pastors exploit the poor, asserting that they do not provide social services, and implying that they do not look after the well-being of their communities. ${ }^{43}$ As, historically, this was a way in which chiefs and other people of power achieved status and legitimacy, such an accusation touches not only upon the material contribution and redistribution of pastors, but also more fundamentally on their legitimacy as religious leaders. Consequently, I argue that charismatic pastors preaching about wealth and prosperity can be perceived as navigating the tension between accumulating for oneself or for the community. This tension between communality and individuality is an embedded part of Akan social thought, as noted by Kwame Gyekye. ${ }^{44}$ Therefore, charismatic pastors must balance this tension when seeking to become recognized as legitimate pastors, and can be accused of being fake if they accumulate mainly for individual consumption. Indeed, many charismatic pastors in Ghana are concerned about the well-being of their community and at the same time preach the prosperity gospel, and we see the notions of sowing and reaping being mixed with a modality of exchange that is based on the moral values of communal well-being. ${ }^{45}$

A related aspect concerns the ways in which pastors accumulate wealth. Often church members would accuse young pastors who got rich too quickly of

\section{$42 \quad$ Lauterbach, Christianity.}

43 T.C. McCaskie writes about a criticism of charismatic pastors in Ghana provided by a traditional priest using a similar argument of charismatic pastors posing a threat to the social cohesion of society because they seek wealth for themselves. T.C. McCaskie, "Akwantemfi-'In mid-journey': An Asante shrine today and its clients," Journal of Religion in Africa 38, no. 1 (2008): 1-24.

44 Kwame Gyekye, An essay on African philosophical thought. The Akan conceptual scheme (Cambridge: Cambridge University Press, 1987).

45 Karen Lauterbach, Christianity; T.C. McCaskie, "Accumulation: Wealth and belief in Asante history: II," Africa 56, no. 1 (1986): 3-23. 
being fake pastors, as they were not accumulating according to morally accepted norms. ${ }^{46}$ Ideas of fast wealth are, moreover, related to fakery as it is often thought that this kind of wealth is accumulated by using evil spiritual forces. One church member offered the following explanation:

For these fake ones [pastors], they get rich overnight. God is a miracle worker, not a sorcerer ... The genuine men of God struggle before they become successful. The fake ones become successful at once without struggle. They go for charms to be able to look into the future and past to impress people. ${ }^{47}$

This comment indicates that the moral compass used when assessing who is genuine and who is fake is not related to who promotes the prosperity gospel or not, or who promotes a commodified version of Christianity, but, rather, to how one has accumulated wealth and, in particular, what kinds of spiritual power have been used in this process. We are dealing with a modality of exchange that touches upon more universal messages of tabooed forms of wealth and especially the dubiousness related to becoming rich too fast. This debate also relates to Fabian's discussion of the possible tension between a commodified form of Christianity and Christianity's reflection of universal messages mentioned above. However, as I have not identified a pure form of commodified Christianity in my work, I would propose that there is also room to deal with universal messages and questions in Ghanaian charismatic Christianity. As the ideology of the prosperity gospel does not appear in a distilled form, ways of dealing with the accumulation of wealth in charismatic Christianity include broader moral concerns.

Fakery is also very much associated with pastors selling religious services, such as prayers, anointing oil, and holy water. Wealth achieved in this way is seen by many as illegitimate wealth. Fast money and the selling of religious services is associated with greed, which has long been a reason for church disputes and the discrediting of pastors (including prior to the rise of charismatic Christianity in the 1980s). This points to an important link between moral values and a pastor's actions. In order to become recognized as a legitimate pastor, one has to act in a morally acceptable and truthful way and, most importantly, what one says and what one does must correspond. Girish Daswani argues along the same lines when observing that the public commentary on pastors is about more than whether they are fake or real, but also "speaks of

$46 \quad$ See also Lindhardt, "More than just."

47 Interview with church member, 11 December 2014, Kumasi, Ghana. 
the virtue or the character of the charismatic prophet, where ethical value is assessed around the criteria for judging the worth of one's actions." ${ }^{m 8}$ The importance here is on how a pastor acts, and not so much on whether or not the pastor encourages church members to give generously in church. One church member explained: "Some of the pastors sell anointing oil. However, when a pastor tells you to bring anointing oil for him to bless it for you, I do not see anything wrong with it. But if he tells you to buy it from him before he prays over it, then it is bad."49 The distinction between what is morally acceptable and what is not, and hence judged as genuine or fake, is based on whether a person gives freely to a pastor or whether money is extracted through selling religious services. The same church member said, "If you know the word of God, you will not let the pastor force you to give, but you would give freely from the heart." Giving in this sense is more than sowing in order to receive a return. It is also about showing gratitude and respect to a pastor or to God, which does not preclude the giver receiving God's blessing in return. There is a fine balance between giving to pastors and the church as a form of offering and paying for a religious service. The former is seen as legitimate and the latter as illegitimate and hence a sign of fakery.

From another perspective, one Ghanaian charismatic pastor talked about the danger of wealth polluting the personality or psychology of those who are successful:

Sometimes, prosperity gets into the head of people. When people begin to do well in ministry, it has its effects. However, if you allow privileges to dictate to you then you begin to think highly of yourself. In spite of all wealth, one must remain simple and humble. When you do that it helps you. ${ }^{50}$

In this extract, the pastor indicates that all pastors experience the risk of being influenced and dictated to by wealth, which affects how you are perceived by others. The perceived danger here is not richness in itself, or being a rich pastor; rather, the issue of concern is how one handles privilege, and how it influences one's moral comportment.

These debates and controversies connected to payment for religious services are related to the moral questions of exploitation, failed promises, and deception referred to above. But how much do we know about church members'

48 Girish Daswani, "A prophet," 110.

49 Interview with church member, 9 December 2014, Kumasi, Ghana.

50 Interview with pastor, 4 December 2014, Kumasi, Ghana. 
own understanding of giving and receiving in church? Do they see themselves as exploited if they are asked to pay in church and do not receive God's blessings? Or if they pay a fee for a deliverance session and are not freed of their problem? Do they see themselves as being victims of fraud, or do they question the spiritual power of a pastor and the unlimited love of God? These questions do not have settled answers and, as I have shown through the above analysis, they need to be addressed in a contextually and historically informed way. In southern Ghana, power has historically brought money, and money has brought power. ${ }^{51}$ Being a rich pastor is therefore not in itself controversial, but one could argue that the emergence of charismatic Christianity has sparked debate around the relationship between wealth and religion, and the moral boundaries of this field, which, for instance, entails moving away from the more ascetic stance taken by many mission churches. On one occasion, when discussing these issues with a pastor, he shared the following reflections with me:

Should people pay money before they are attended to, like a medical doctor at the hospital? Is the priest enjoined to do same? Is he forcing the people to do that? But healing is not procured, but a free gift, and if you procure healing then it's not biblical. I don't know the type of realm we can put that. ${ }^{52}$

The questions were many, and he did not have definite answers. This pastor was not against offering in church or church members giving money to their pastors. He was of the view that if a pastor has a talent and uses it well, he should and would become rich. There are many instances of pastors and church members having debates about the parameters within which giving and receiving money in church should take place. This indicates that how people relate to and practice forms of exchange in religious settings are not influenced by one set of ideas or ideology, such as the prosperity gospel. As discussed throughout this chapter, people (both church members and pastors) draw on several moralities and modalities of exchange when giving and receiving in church.

Moreover, and as pointed out by Kwabena Asamoah-Gyadu, in the Ghanaian context prosperity is not only understood as material richness, but is also about enjoying "benefits [such] as forgiveness of sins, healing, redemption of

51 T.C. McCaskie, State and society in pre-colonial Asante (Cambridge: Cambridge University Press, 1995). 
our lives from destruction and crowning us with tender mercies." ${ }^{33}$ This indicates that, in this context, the prosperity gospel is not solely about material riches; rather, the term prosperity has a wider meaning that includes both material and non-material blessings.

\section{Conclusion}

This chapter has engaged in a critical discussion of the prosperity gospel as a single theological message or as a script. It has pointed to the analytical limitations of the adoption of such an approach as it marginalizes and renders invisible other moralities of exchange that co-exist and overlap with the prosperity gospel. I have argued that if we approach the study of material and symbolic wealth in African charismatic Christianity differently, with more emphasis on historical and contextual perspectives, we reach a different and perhaps more nuanced understanding of the role of wealth in this form of Christianity. This can be done by drawing on concepts that lie outside of the prosperity gospel itself; in this way, we separate the object of analysis from the analytical lens. I have argued that different modalities of exchange are in play that involve a broad understanding of wealth and prosperity, and also the meanings that are ascribed to giving and receiving in church. The fundamental principle of sowing and reaping is in one way unique to charismatic Christianity, but it also represents a more fundamental mechanism of giving and receiving which is present in a number of religious settings. I argue for an analysis of wealth in charismatic Christianity in Africa that does not perceive giving and receiving only as an investment in economic terms or as a priori incompatible with Christianity. I have suggested studying wealth in charismatic Christianity through the idiom of fakery in order to understand how and when giving and receiving in church is thought of as illegitimate and legitimate. The point is that this does not only and always follow the basic principles of the prosperity theology, but rather involves a range of different moralities placed within and outside this particular Christian setting. Combining an anthropologically inspired analysis with a focus on ordinary theology is fruitful for such a task, because it allows us to see modalities of exchange beyond the script, and yet have an openness to (everyday) theological thinking and religious reasoning. 


\section{References}

Asamoah-Gyadu, J. Kwabena. African Charismatics. Current Developments within Independent Indigenous Pentecostalism in Ghana. Leiden: Brill, 2005.

Astley, Jeff. "The Analysis, Investigation and Application of Ordinary Theology." In Exploring Ordinary Theology: Everyday Christian Believing and the Church, edited by Jeff Astley and Leslie J. Francis, 1-9. Farnham: Ashgate, 2013.

Coleman, Simon. "Between Faith and Fraudulence? Sincerity and Sacrifice in Prosperity Christianity." In Minority Religions and Fraud: In Good Faith, edited by Amanda van Eck Duymaer van Twist, 73-89. London: Ashgate Publishing, 2014.

Coleman, Simon. "Morality, Markets, and the Gospel of Prosperity." In Religion and the Morality of the Market, edited by Daromir Rudnyckuj and Filippo Osella, 50-71. Cambridge: Cambridge University Press, 2017.

Comaroff, Jean and John Comaroff. "Second comings: neo-Protestant ethics and millennial capitalism in Africa, and elsewhere." In 2000 Years and Beyond: Faith, Identity and the 'Common Era', edited Paul Gifford, 106-126. London: Routledge, 2003.

Daswani, Girish. "A prophet but not for profit: ethical value and character in Ghanaian Pentecostalism." Journal of the Royal Anthropological Institute 22, no. 1 (2016): 108-126.

Fabian, Johannes. Talk About Prayer: An Ethnographic Commentary. New York: Palgrave Macmillan, 2015.

Festinger, Leon, Henry W. Riechen and Stanley Schachter. When Prophecy Fails. Minneapolis: University of Minnesota Press, $195^{6}$.

Gifford, Paul. "The Complex Provenance of Some Elements of African Pentecostal Theology." In Between Babel and Pentecost: Transnational Pentecostalism in African and Latin America, edited by André Corton and Ruth Marshall-Fratani, 62-79. Bloomington and Indianapolis: Indiana University Press, 2001.

Gifford, Paul. Ghana's New Christianity: Pentecostalism in a Globalising African Economy. London: Hurst \& Company, 2004.

Gifford, Paul. Christianity, Development, and Modernity in Africa. London: Hurst \& Company, 2015.

Gyekye, Kwame. An essay on African philosophical thought. The Akan conceptual scheme. Cambridge: Cambridge University Press, 1987.

Harrison, Milmon. Righteous Riches: The Word of Faith Movement in Contemporary African American Religion. Oxford: Oxford University Press, 2005.

Haynes, Naomi. "Pentecostalism and the morality of money: prosperity, inequality, and religious sociality on the Zambian Copperbelt." Journal of the Royal Anthropological Institute 18, no. 1 (2012): 123-139.

Heuser, Andreas. "Charting African Prosperity Gospel economies." HTS Teologiese Studies/Theological Studies 72, no. 4 (2016): 1-9. 
Klaits, Frederick. "Asking in Time." In The Request and the Gift in Religious and Humanitarian Endeavors, edited by Frederick Klaits, 1-24. Cham: Palgrave Macmillan, 2017.

Lauterbach, Karen. "Religious entrepreneurs in Ghana." In Cultural Entrepreneurship in Africa, edited by Ute Röschenthaler and Dorothea Schulz, 19-36. Routledge, 2016.

Lauterbach, Karen. Christianity, Wealth, and Spiritual Power in Ghana. New York: Palgrave Macmillan, 2017.

Lindhardt, Martin. "More than just money: The faith gospel and occult economies in contemporary Tanzania." Nova Religio 13, no. 1 (2009): 41-67.

Lindhardt, Martin. "Miracle Makers and Money Takers: Healers, Prosperity Preachers and Fraud in Contemporary Tanzania." In Minority Religions and Fraud: In Good Faith, edited by Amanda van Eck Duymaer van Twist, 153-170. London: Ashgate Publishing, 2014.

McCaskie, T.C. "Accumulation: Wealth and belief in Asante history: II." Africa 56, no. 1 (1986): $3-23$.

McCaskie, T.C. State and society in pre-colonial Asante. Cambridge: Cambridge University Press, 1995 .

McCaskie, T.C. “Akwantemfi-'In mid-journey': An Asante shrine today and its clients.” Journal of Religion in Africa 38, no. 1 (2008): 1-24.

Meyer, Birgit. "Pentecostalism and Neo-Liberal Capitalism: Faith, Prosperity and Vision in African Pentecostal-Charismatic Churches." Journal for the Study of Religion 20, no. 2 (2007): $5^{-28}$.

Obadare, Ebenezer. "'Raising righteous billionaires': The prosperity gospel reconsidered." HTS Teologiese Studies/Theological Studies 72, no. 4 (2016):1-8.

Osella, Filippo and Daromir Rudnyckyj. "Introduction: Assembling Market and Religious Moralities." In Religion and the Morality of the Market, edited by Daromir Rudnyckuj and Filippo Osella, 1-28. Cambridge: Cambridge University Press, 2017.

Peel, J.D.Y. Religious encounter and the making of the Yoruba. Bloomington: Indiana University Press, 2000.

Robbins, Joel. "Afterword: Let's keep it awkward: Anthropology, theology, and otherness." The Australian Journal of Anthropology 24, no. 3 (2013): 329-337.

Ukah, Asonzeh FK. "Those who trade with God never lose: The economics of Pentecostal activism in Nigeria." In Christianity and social change in Africa: Essays in honor of JDY Peel, edited by Toyin Falola, 253-274. Durham: Carolina Academic Press, 2005.

Vähäkangas, Mika. “The Prosperity Gospel in the African Diaspora: Unethical Theology or Gospel in Context?," Exchange 44, no. 4 (2015): 353-380.

Van Eck Duymaer van Twist, Amanda. "Introduction." In Minority Religions and Fraud: In Good Faith, edited by Amanda Van Eck Duymaer van Twist, 1-15. London: Ashgate Publishing, 2014.

Van Wyk, Ilana. The Universal Church of the Kingdom of God in South Africa: A Church of Strangers. Cambridge: Cambridge University Press, 2014. 
Weber, Max. The Protestant Ethic and the Spirit of Capitalism. London and New York: Routledge, [1930] 2001.

Yong, Amos. "A Typology of Prosperity Theology: A Religious Economy of Global Renewal or a Renewal Economics?" In Pentecostalism and Prosperity: The SocioEconomics of the Global Charismatic Movement, edited by K. Attansi and A. Yong, 15-33. Palgrave Macmillan, 2012. 